\title{
Foreign Direct Investment and Business Creation in China
}

\author{
Shiyong Zhao ${ }^{1}$ Yi Huang 2,* \\ ${ }^{1}$ Department of Business, Macau University of Science and Technology, Avenida Wai Long, Taipa, Macau, China \\ ${ }^{2}$ Department of Business, Macau University of Science and Technology, Avenida Wai Long, Taipa, Macau, China \\ *Corresponding author. Email: huangyift@outlook.com
}

\begin{abstract}
This paper studies the impact of foreign direct investment on local business creation by using a panel data set containing 31 provinces of China over 1992-2017. The study finds that the effect is positive and significant. The results are robust to alternative sets of control variables and different estimation strategies and different sample periods. On average about 16 percent of China's local business creation growth can be attributed to FDI inflow over the entire sample period. The knowledge diffusion and technology transfer effect more than offset the crowding-out effect of FDI on local business creation in general during China's economic transition.
\end{abstract}

Keywords: Foreign Direct Investment, Business Creation, China

\section{INTRODUCTION}

Both foreign direct investment (FDI) and local business creation are major sources of economic growth in emerging economies, which have been studied extensively in the literature (Yao and Wei, 2007; Zhao, 2013). ${ }^{[1][2]}$ However, little work looks at the impact of FDI on local business creation. This is precisely what I do in this paper, using a dataset of Chinese provinces in the process of the country's market transition. FDI implies the flow of capital, technology and knowledge across national borders, which creates opportunities for host economies, especially for developing nations (Caves, 1996; Markusen and Veneables, 1999; Javorcik, 2004). ${ }^{[3][4][5]}$ Does the inflow of FDI promote local business creation of host economies or inhibit it? Or is FDI a blessing or curse for local business creation?

Both positive and negative effects of FDI on local business creation are logically valid (Meyer, 2004). ${ }^{[6]}$ Positive spillovers on host economies are illustrated in terms of diffusion of new technologies, management practices, creation of new markets, subcontracting activities, access to critical resources and even financial support (Albulescu and Tamasila, 2014). ${ }^{[7]}$ Negative spillover effects occur when foreign-owned firms compete for the same employees and customers and 'crowd out' domestic firms (De Backer \& Sleuwaegen, 2003). ${ }^{[8]}$ Foreign firms in an industry may negatively impact the entry of local investors by raising the technological barriers to entry (Ayyagari and Kosova, 2010). ${ }^{[9]}$ This crowding-out effect is because foreign companies competing in developing countries are usually more technologically advanced. Thus, there are potentially two opposing effects of FDI on local business creation. Only through empirical studies can we answer this kind of 'blessing or curse' questions. The net effect of FDI on local business creation is inconclusive because it depends on which of the two effects dominates. It may be different in different countries over different time periods. I believe it is an intriguing question in the context of China's transition and development, which I attempt to answer in this paper.

\section{FDI AND LOCAL BUSINESS CREATION: A BRIEF LITERATURE REVIEW}

\section{1. 'Blessing' argument}

The 'blessing' (positive spillover) argument is based on the diffusion of technology and knowledge from foreign firms to domestic businesses. Caves (1996) argues that foreign investors possess more advanced technologies and superior management practices compared with their local counterparts. ${ }^{[10]}$ Once foreign firms enter a domestic market, the transfer of technology and diffusion of ideas resulting from interaction with local economy is likely to occur, both 
within and across industries (Javorcik, 2004; Haskel et al., 2007). ${ }^{[1]}$

Demonstration effect or contagion-imitation effect is one of the channels through which knowledge diffuses (Findlay, 1978; Kokko, 1992; Barry et al. 2003). ${ }^{[12][13][14]}$ Demonstration effect works through the direct contact between local agents and a foreign firm operating at different levels of technology (Meyer, 2004). This effect is most likely to be observed horizontally (within an industry). Moreover, because the technologies and practices of foreign firms have been tested in the market, domestic entrepreneurs can recognize their viability and convert them into profitable undertakings in a shorter period of time and with less risk of failure.

Another mechanism through which technology and knowledge diffuse to local economy is labor mobility (Fosfuri et al., 2001). ${ }^{[15]}$ Foreign firms have to hire and train local workers. Through learning by doing and watching, these employees will be equipped with new skills on technology, strategy and operations. They can take jobs in local enterprises or start their own businesses. Furthermore, with labor mobility and interaction, tacit knowledge on modern market economy and business operations are diffused to the local economy, which will spur local potential entrepreneurs to create their own businesses. The literature on peer effects suggests that spillovers operate powerfully inside firms (Mas and Moretti, 2009; Bandiera et al., $2010)^{[16][17]}$, and there is a long history of work connecting the transfer of knowledge to physical proximity (for example, Sandvik et al., 2020). ${ }^{[18]}$ So, labor mobility can generate spillovers as employees trained by foreign firms may use their skills to improve local firms' performance, thus enhance local business creation.

\section{2. 'Blessing' argument}

The 'curse' argument is based on the so-called 'crowding-out' effect or 'market-stealing' effect (De Backer and Sleuwagen, 2003). Foreign firms may attract capital and labor that may otherwise be employed in local firms, thus inhibiting their growth and productivity (Meyer, 2004). The entry of foreign firms increases competitive pressures on domestic ones, which may drive less efficient local firms out of the market (Djankov and Hoekman, 2000). ${ }^{[19]}$ Presence of foreign firms in an industry can have a negative impact on the entry of domestic firms by raising the technological barriers to entry (Ayyagari \& Kosová, 2010). This happens because foreign firms are usually more technologically advanced than their counterparts in the host countries. If local enterprises fail to adopt superior technology and to improve their productivity in response to the increased competition from the foreign entrant, they will be forced to exit.

FDI increases the opportunity cost of starting a business for potential entrepreneurs in the host country, especially in developing nations or emerging markets. Given the wage structures offered by foreign companies are typically more attractive by domestic standards, especially to skilled or managerial labor, potential entrepreneurs may take positions in these firms as salaried employees in preference to entrepreneurial activities. In this way potential entrepreneurs might thus instead become tied up as employees of foreign firms rather than start their own businesses (De Backer and Sleuwaegen, 2003). Moreover, foreign firms may divert a significant amount of domestic factor endowments (for example, finance, managerial and skilled labor) to themselves, raising the costs of entry for domestic entrepreneurs. Related to this argument, Grossman(1984) argues that inflows of FDI 'serves to impede the development of the entrepreneurial class. ${ }^{\text {[20] }}$ Therefore, by attracting potential entrepreneurs into wage employment, it is plausible to expect that FDI presence exerts negative effects on domestic firm formation.

\section{MODEL}

The econometric model I use in this paper is constructed as follows:

$$
\begin{aligned}
& \text { busi_creation }=\beta_{1} \log \left(f d i_{i t}\right)+\beta_{2} \text { lgrowt }_{i t} \\
& +\beta_{3} \text { elderly }_{i t}+\beta_{4} \text { birth }_{i t}+\beta_{5}(\text { govt } / g d p)_{i t} \\
& +\beta_{6} \log \left(\text { eduction }_{i t}\right)+\beta_{7} \log \left(\text { road }_{i t}\right) \\
& +\beta_{8}(\text { loan } / g d p)_{i t}+\beta_{9}(\text { invest } / g d p)_{i t} \\
& +\beta_{10} \text { policy_99 }+\beta_{11} \text { policy_04 } \\
& +\beta_{12} \text { year_dum }+\eta_{i}+\varepsilon_{i t}
\end{aligned}
$$

Where $\mathrm{i}$ stands for province $(\mathrm{i}=1, \ldots, 31)$, and $\mathrm{t}$ denotes year, representing years 1992-2017. Here, $\eta_{i}$ Is a province fixed effect: it represents all factors affecting provincial business creation that do not change over time. Year_dum are year dummies. $\varepsilon_{\text {it }}$ Are idiosyncratic errors. Definitions (or measurements) of all variables are summarized in Table 1.

Table 1. Variables and definitions

\begin{tabular}{|l|l|}
\hline Variable & Definition \\
\hline Business creation & Private employment as a share of total urban employment (percent) \\
\hline Fdi & Stock of FDI actually utilized per capita (USD) \\
\hline Lgrowth & GDP growth rate of the previous year \\
\hline Elderly & Elderly dependency ratio (percent) \\
\hline Birth & Birth rate (1/1000) \\
\hline
\end{tabular}




\begin{tabular}{|l|l|}
\hline Govt/gdp & Government expenditure as a share of GDP (percent) \\
\hline Education & University student enrollments per 10,000 people \\
\hline Road & Mileage (km) of road per 10,000 km squared of land \\
\hline Loan/gdp & Total loans of financial institutions divided by GDP (percent) \\
\hline Invest/gdp & Fixed asset investment as a share of GDP (percent) \\
\hline Policy_99 & Equals 1 if years are between 1999 and 2004 (inclusive); 0 otherwise \\
\hline Policy_04 & Equals 1 if years are between 2004 and 2017 (inclusive); 0 otherwise \\
\hline
\end{tabular}

The amendment to the Constitution approved at the Second Plenary Session of the Ninth People's Congress on March15, 1999 for the first time recognized that 'the nonpublic sector, including individual and private businesses. This is a landmark for China's entrepreneurial development. Five years later, the amendment to the Constitution approved at the Second Plenary Session of the Tenth People's Congress on March 14, 2004 remarked that 'the state protects the private property rights and inheritance of the citizens according to the law.' This is also a milestone for China's private investors and entrepreneurs. Therefore, I include two policy dummies in our regression equation. Dummy variable policy_99 refers to the period between 1999 and 2004 (inclusive). And Dummy policy_04 refers to the period between 2004 and 2017 (inclusive). Considering data availability and statistical consistency, I use 'the fraction of urban private sector employment' to measure business creation in this paper. An entrepreneur may start a new private enterprise, expand an existing private enterprise, or privatize a state-owned enterprise. The common effect is that more people will be working in the private sectors, which usually gives rise to a higher percentage of private sector employment in the economy.

With regard to FDI in the regression equation, I clarify the following four points. First, I use FDI actually utilized rather than FDI contracted. Both figures are available in China's official statistics, but only FDI actually utilized plays the role. Second, I use per capita FDI rather than total FDI, because different provinces have different populations. Third, I use real rather than nominal FDI. We convert current price FDI into constant price FDI with U.S. CPI (2000 as the base year). Finally, I use the stock rather than the flow of FDI, because in any year all the existed FDI plays the role. I use an annual depreciation rate of 5 percent to calculate the FDI stock in each year.

The problem of endogeneity is usually present. There must be some factors which both affect business creation and FDI, such as government policies. Therefore, I control for variables like the previous year GDP growth rate and demographic factors including elderly dependency ratio and birth rate. I also control for government's role, so I include variables like government expenditures as a share of GDP, and infrastructure. Moreover, variables measuring human capital, financial service, fixed asset investment, and policy dummies are controlled for in some regressions.

\section{REGRESSION RESULTS}

The data used in this paper come from China Statistical Yearbook (relevant years) and Statistical Yearbook of each province (relevant years). The former was compiled and published by National Bureau of Statistics (NBS), China' s central statistical authority, and the latter, provincial-level statistical bureaus. The data set consists of 31 provinces of China over 19922017. Tables 2 and 3 present descriptive statistics and correlation matrix of the variables.

Table 2. Summary statistics (1992-2017)

\begin{tabular}{|l|l|l|l|l|l|}
\hline Variable & Obs. & Mean & Std. Dev & Min & Max \\
\hline $\begin{array}{l}\text { Business } \\
\text { creation }\end{array}$ & 782 & 31.6 & 19.0 & 0 & 80.3 \\
\hline Fdi & 806 & 631 & 1109 & 0 & 9116 \\
\hline Lgrowth & 806 & 0.11 & 0.03 & -0.03 & 0.41 \\
\hline Elderly & 762 & 11.5 & 2.92 & 4.97 & 24.5 \\
\hline Birth & 804 & 12.8 & 4.01 & 4.28 & 24.9 \\
\hline Govt/GDP & 806 & 19.3 & 16.1 & 4.92 & 138 \\
\hline Education & 806 & 111 & 82.7 & 7.94 & 399 \\
\hline Road & 806 & 5569 & 4606 & 157 & 25149 \\
\hline Loan/GDP & 805 & 106 & 36.2 & 29.2 & 308 \\
\hline Invest/GDP & 806 & 53.8 & 25.4 & 17.39 & 156 \\
\hline
\end{tabular}


Table 3. Correlation matrix (1992-2017)

\begin{tabular}{|l|c|c|c|c|c|c|c|c|c|}
\hline & 1 & 2 & 3 & 4 & 5 & 6 & 7 & 8 & 9 \\
\hline $\begin{array}{l}\text { Business } \\
\text { creation }\end{array}$ & & & & & & & & & \\
\hline Fdi & 0.45 & & & & & & & & \\
\hline Lgrowth & 0.04 & 0.13 & & & & & & & \\
\hline Elderly & 0.54 & 0.60 & 0.13 & & & & & & \\
\hline Birth & -0.31 & -0.66 & -0.08 & -0.53 & & & & & \\
\hline Govt/GDP & 0.40 & -0.08 & -0.04 & -0.02 & 0.15 & & & & \\
\hline Education & 0.60 & 0.76 & 0.05 & 0.61 & -0.68 & 0.25 & & & \\
\hline Road & 0.44 & 0.70 & 0.11 & 0.73 & -0.53 & -0.20 & 0.64 & & \\
\hline Loan/GDP & 0.16 & 0.21 & -0.25 & 0.05 & -0.09 & 0.22 & 0.26 & 0.13 & \\
\hline Invest/GDP & 0.57 & 0.34 & 0.07 & 0.40 & -0.14 & 0.59 & 0.62 & 0.29 & 0.18 \\
\hline
\end{tabular}

Table 4. Impact of FDI on Local Business creation (31 provinces, fixed effect)

\begin{tabular}{|c|c|c|c|c|c|c|}
\hline Independent & Dependent vari & siness crea & $92-2001)$ & Dependent var & siness crea & $\overline{01-2017)}$ \\
\hline & (1) & (2) & (3) & (4) & (5) & (6) \\
\hline $\log (\mathrm{fdi})$ & $\begin{array}{l}4.94 * * * \\
(0.57)\end{array}$ & $\begin{array}{c}3.46^{* *} \\
(1.00)\end{array}$ & $\begin{array}{l}3.44 * * * \\
(1.00)\end{array}$ & $\begin{array}{l}8.87 * * * \\
(0.71)\end{array}$ & $\begin{array}{l}4.81 * * * \\
(0.57)\end{array}$ & $\begin{array}{l}4.69 * * * \\
(0.46)\end{array}$ \\
\hline Lgrowth & $\begin{array}{l}-0.31 * * * \\
(0.08)\end{array}$ & $\begin{array}{r}-0.22 * * \\
(0.08)\end{array}$ & $\begin{array}{l}-0.22 * * \\
(0.10)\end{array}$ & $\begin{array}{l}-0.03 \\
(0.21)\end{array}$ & $\begin{array}{l}-0.48 * * * \\
(0.13)\end{array}$ & $\begin{array}{l}-0.38 * * * \\
(0.11)\end{array}$ \\
\hline Elderly & $\begin{array}{l}1.93^{* * *} \\
(0.77)\end{array}$ & $\begin{array}{c}2.23 * * \\
(0.83)\end{array}$ & $\begin{array}{l}2.25 * * \\
(0.82)\end{array}$ & $\begin{array}{l}0.18 \\
(0.35)\end{array}$ & $\begin{array}{l}-0.25 \\
(0.24)\end{array}$ & $\begin{array}{l}-0.27 \\
(0.24)\end{array}$ \\
\hline Birth & $\begin{array}{l}-0.33 \\
(0.28) \\
\end{array}$ & $\begin{array}{c}0.02 \\
(0.33)\end{array}$ & $\begin{array}{l}0.01 \\
(0.34) \\
\end{array}$ & $\begin{array}{l}0.38 \\
(0.25) \\
\end{array}$ & $\begin{array}{l}0.53^{*} \\
(0.28) \\
\end{array}$ & $\begin{array}{l}0.46 \\
(0.31) \\
\end{array}$ \\
\hline Govt/gdp & $\begin{array}{l}0.66^{* * * *} \\
(0.11)\end{array}$ & $\begin{array}{c}0.37 * * \\
(0.07)\end{array}$ & $\begin{array}{l}0.36^{* * * *} \\
(0.09)\end{array}$ & $\begin{array}{l}0.16^{*} \\
(0.09)\end{array}$ & $\begin{array}{l}-0.07 \\
(0.06)\end{array}$ & $\begin{array}{l}-0.13 * * * \\
(0.04)\end{array}$ \\
\hline Log(education) & & $\begin{array}{c}7.00 * * \\
(2.21)\end{array}$ & $\begin{array}{l}6.64 * * \\
(2.27)\end{array}$ & & $\begin{array}{l}10.1 * * * \\
(1.38)\end{array}$ & $\begin{array}{l}9.53 * * * \\
(1.55)\end{array}$ \\
\hline $\log ($ road $)$ & & $\begin{array}{l}0.16 \\
(1.99)\end{array}$ & $\begin{array}{l}0.48 \\
(1.91)\end{array}$ & & $\begin{array}{l}1.66 \\
(1.98)\end{array}$ & $\begin{array}{l}2.00 \\
(2.10)\end{array}$ \\
\hline Loan/gdp & & & $\begin{array}{l}0.001 \\
(0.02)\end{array}$ & & & $\begin{array}{l}0.03 \\
(0.02)\end{array}$ \\
\hline Invest/gdp & & & $\begin{array}{l}0.02 \\
(0.05)\end{array}$ & & & $\begin{array}{l}0.01 \\
(0.03)\end{array}$ \\
\hline Constant & $\begin{array}{l}-22.5 * * \\
(9.56)\end{array}$ & $\begin{array}{l}-46.7^{*} \\
(25.4)\end{array}$ & $\begin{array}{l}-48.5^{*} \\
(25.6)\end{array}$ & $\begin{array}{l}-21.2 * * \\
(7.89)\end{array}$ & $\begin{array}{l}-47.6^{* * * *} \\
(11.3)\end{array}$ & $\begin{array}{l}-49.9 * * * \\
(13.7)\end{array}$ \\
\hline Observations & 298 & 298 & 297 & 463 & 463 & 463 \\
\hline Within R-sq. & 0.565 & 0.580 & 0.578 & 0.505 & 0.550 & 0.552 \\
\hline Adj. R-sq. & 0.736 & 0.742 & 0.739 & 0.792 & 0.810 & 0.810 \\
\hline
\end{tabular}

Note. (1) Figures in parentheses are Driscoll and Kraay (1988) standard errors. (2) All six models are one-way fixed effect models. (3) $*$, ** and $* * *$ denote statistical significance at 10 percent, 5 percent, and 1 percent level, respectively.

Table 5. Impact of FDI on Local Business creation (31 provinces)

\begin{tabular}{|c|c|c|c|c|c|}
\hline \multirow{2}{*}{$\begin{array}{c}\text { Independent } \\
\text { Variables }\end{array}$} & \multicolumn{5}{|c|}{ Dependent variable: Business creation } \\
\cline { 2 - 6 } & $\begin{array}{c}1992-2001 \\
\text { Two-way FE }\end{array}$ & $\begin{array}{c}2001-2017 \\
\text { Two-way FE }\end{array}$ & $\begin{array}{c}1992-2017 \\
\text { One-way FE }\end{array}$ & $\begin{array}{c}1992-2017 \\
\text { Two-way FE }\end{array}$ & $\begin{array}{c}1992-2017 \\
\text { Two-way FE }\end{array}$ \\
\hline & $(7)$ & $(8)$ & $(9)$ & $(10)$ & $(11)$ \\
\hline $\log ($ fdi) & $2.53^{* *}$ & $2.05^{* * *}$ & $3.49^{* * *}$ & $3.51^{* * *}$ & $3.08^{* * *}$ \\
& $(0.87)$ & $(0.68)$ & $(0.55)$ & $(0.93)$ & $(0.70)$ \\
\hline Lgrowth & $-0.12^{*}$ & -0.08 & -0.10 & -0.16 & 0.005 \\
\hline
\end{tabular}




\begin{tabular}{|c|c|c|c|c|c|}
\hline & $(0.06)$ & $(0.17)$ & $(0.07)$ & $(0.13)$ & $(0.10)$ \\
\hline Elderly & $\begin{array}{l}2.17 * * \\
(0.88)\end{array}$ & $\begin{array}{l}-0.10 \\
(0.28)\end{array}$ & $\begin{array}{l}0.79 * \\
(0.44)\end{array}$ & $\begin{array}{l}0.96^{*} \\
(0.49)\end{array}$ & $\begin{array}{l}1.13 * * \\
(0.48)\end{array}$ \\
\hline Birth & $\begin{array}{l}0.18 \\
(0.31)\end{array}$ & $\begin{array}{l}0.07 \\
(0.22)\end{array}$ & $\begin{array}{l}-0.13 \\
(0.19)\end{array}$ & $\begin{array}{l}-0.44 * \\
(0.24)\end{array}$ & $\begin{array}{l}-0.36 \\
(0.25)\end{array}$ \\
\hline Govt/gdp & $\begin{array}{l}0.25 \\
(0.14)\end{array}$ & $\begin{array}{l}-0.21 * \\
(0.11)\end{array}$ & $\begin{array}{l}0.22 * * \\
(0.10)\end{array}$ & $\begin{array}{l}0.05 \\
(0.11)\end{array}$ & $\begin{array}{l}0.05 \\
(0.12)\end{array}$ \\
\hline Log(education) & $\begin{array}{l}3.82 \\
(6.20)\end{array}$ & $\begin{array}{l}-4.21 * * \\
(1.52)\end{array}$ & $\begin{array}{l}6.80 * * * \\
(1.01)\end{array}$ & $\begin{array}{l}-3.63 \\
(2.70)\end{array}$ & $\begin{array}{l}1.42 \\
(2.28)\end{array}$ \\
\hline Log(road) & $\begin{array}{l}-0.66 \\
(2.27)\end{array}$ & $\begin{array}{l}-3.94 * \\
(2.09)\end{array}$ & $\begin{array}{l}3.94 * * \\
(1.77)\end{array}$ & $\begin{array}{l}-0.18 \\
(1.93)\end{array}$ & $\begin{array}{l}0.02 \\
(1.82)\end{array}$ \\
\hline Loan/gdp & $\begin{array}{l}-0.02 \\
(0.02)\end{array}$ & $\begin{array}{l}0.02 \\
(0.03)\end{array}$ & $\begin{array}{l}0.05 * * * \\
(0.02)\end{array}$ & $\begin{array}{l}0.05 * * * \\
(0.02)\end{array}$ & $\begin{array}{l}0.05 * * * \\
(0.02)\end{array}$ \\
\hline Invest/gdp & $\begin{array}{l}0.02 \\
(0.06)\end{array}$ & $\begin{array}{l}0.03 \\
(0.03)\end{array}$ & $\begin{array}{l}-0.07 * * \\
(0.03)\end{array}$ & $\begin{array}{l}-0.04 \\
(0.04)\end{array}$ & $\begin{array}{l}-0.07^{*} \\
(0.04)\end{array}$ \\
\hline Policy_99 & & & & & $\begin{array}{l}7.13 * * \\
(3.35)\end{array}$ \\
\hline Policy_04 & & & & & $\begin{array}{l}12.3^{* * * *} \\
(3.63)\end{array}$ \\
\hline Year dummies & Included & Included & Excluded & Included & Included \\
\hline Constant & $\begin{array}{l}-28.5 \\
(37.9)\end{array}$ & $\begin{array}{l}\text { 64.9*** } \\
(13.5)\end{array}$ & $\begin{array}{l}-60.8 * * * \\
(10.8)\end{array}$ & $\begin{array}{l}8.45 \\
(20.2)\end{array}$ & $\begin{array}{l}-11.6 \\
(12.4)\end{array}$ \\
\hline Observations & 297 & 463 & 729 & 729 & 729 \\
\hline Within R-sq. & 0.594 & 0.620 & 0.759 & 0.782 & 0.774 \\
\hline Adj. R-sq. & 0.744 & 0.812 & 0.822 & 0.835 & 0.830 \\
\hline
\end{tabular}

Note. (1) Figures in parentheses are Driscoll and Kraay (1988) standard errors. (2) *,** and *** denote statistical significance at 10 percent, 5 percent, and 1 percent level, respectively.

In Table 4, I break the entire sample period into two sub-periods, one is from 1992-2001, and the other is from 2001-2017. In each sum-period, I control for different sets of variables. Table 4 reports the results of 6 models. The results of all models show that FDI had positively influenced China's local business creation over the two subperiods. Take Models (3) as an example, when per capital FDI increases by 1 percent, local business creation (urban private sectors employment share) will increase by 0.03 percentage points over 1992-2001. In the second sum-period (20012017), the effect was even stronger, local business creation will increase by about 0.05 percentage points if per capital FDI increases by 1 percent.

As robustness tests, in Model (7), I implement a two-way fixed effects regression by controlling for year dummies (full set of control variables are included) for the first sub-period. Model (8) is for the second subperiod. Models (9) and (10) implement one-way and two-way fixed effect regressions respectively over the entire sample period. In Model (11), I add two policy dummies into the regression besides the variables in Model (10). The results of all the five models in Table 5 show that FDI had played a significant positive role in local business creation in China. The estimated coefficient on FDI does not change much in the two tables, all the estimates are statistically significant at the 1 percent level (except in Model (7) with a 5 percent significance level). The findings in all the 11 models suggest that FDI was a 'blessing' for China's local business creation development. Results in Model (11) show that the policy effects of 1999 and 2004 are both significant. Two amendments to the Constitution have significantly stimulated China's local business creation.

\section{EXPLANATIONS AND DISCUSSIONS}

Theoretically FDI is a 'double-edged sword' to local business creation. China's experience suggests that the positive effect dominates. I offer three possible explanations of this result.

First, FDI inflow was the best way to transfer technology and transmit knowledge on modern business operations to China in the 1980s and early 1990s. One of the biggest obstacles to China's local business creation development was lack of knowledge on market economy in general land modern business operations in particular after thirty years of planned economy since the 1950s. Most Chinese people were ignorant to modern market knowledge in the 1980s and China's local business creation was basically absent. Against this background technology and knowledge diffusion from foreign firms to host economies was more likely to happen than FDI's crowding-out effect. Foreign firms, being equipped with more advanced technology and modern knowledge on business operations, came to China to earn money, but at the same time, the technology and knowledge displayed themselves before the Chinese people. Foreign investors were not educators, nor did they intend to teach anybody, but the consequence was that Chinese people learned what they need to learn.

Second, one of the main obstacles to China's local business creation, apart from the aforementioned lack of knowledge, was Marxist ideology. Under this ideology, 
public ownership was highly acclaimed, but private businesses were viewed as low status and discriminated against. During China's transition, debates on 'capitalist or socialist' and 'public or private' had been acute and extensive. Not until 1997 did Chinese government officially recognize private businesses as 'an important part of the socialist market economy.' By that time, foreign businesses had been operating in China for 19 years. The successful performance of foreign companies and their positive effects on the local economy (especially in the four special economic zones in the 1980s) facilitated a strategic shift in the official ideology towards the complete abandonment of planned economy and the embracing of a market system with private ownership. The presence and development of foreign businesses in China presumably attenuate the resistance from socialist ideology to local business creation and pave the way for the growth of business creation later on.

Third, China has an innate advantage in attracting and utilizing FDI from Hong Kong, Macau and Taiwan because of the 'special' relationship between the two sides. Hong Kong and Taiwan started to take off economically in the 1960 s and became developed economies by the 1980s during which mainland China was a closed and backward economy. China initiated the reform and opening-up policy in the late 1970s. In the 1980s FDI was mainly from Hong Kong and Macau (Communications between mainland and Taiwan were not open until 1987). For example, in 1987, FDI from Hong Kong and Macau accounted for 69 percent of total FDI inflow into China (NBS, 1988); in 2017, 72 percent of FDI inflow into China was from Hong Kong (NBS, 2018). ${ }^{[21]}$ During China's transition and development, investors from Hong Kong, Macau and Taiwan have played a huge and irreplaceable role in diffusing knowledge on market economy because of both geographical proximity and cultural proximity.

\section{CONCLUSION}

Using data containing 31 provinces of China over 1992-2017, I find that FDI had a statistically positive and significant effect on local business creation in China. The results are robust to different sets of control variables and different estimation techniques. By controlling for the full set of variables and year dummies, our two-way fixed effect regression reports that when per capita FDI increases by 1 percent, local business creation will increase by 0.03 percentage points over 1992-2017. On average, 16 percent of local business creation growth can be attributed to FDI in China over this period.

The finding in this paper does not support the 'curse' view of Grossman (1984), who asserts that foreign investment 'inhibits the development of an entrepreneurial class' in the host economy. I argue that this positive net effect of FDI on local business creation in China is not surprising for several reasons. FDI mitigated the formidable obstacle of socialist ideology to private businesses. Hong Kong, Macau, and Taiwan played a special role in promoting the positive spillover of FDI in China because of both geographical and cultural proximity. Moreover, China is a big market in which foreign firms only account for a small part of it, which dwarfs the negative crowding-out effect of FDI on local business creation.

\section{REFERENCES}

[1] S.J. Yao, K.L. Wei, Economic Growth in the Presence of FDI: The Perspective of Newly Industrializing Economies, Journal of Comparative Economics 35(1) (2007) 211-234. DOI: https://doi.org/10.1080/13504850600905022

[2] S. Zhao, Privatization, FDI Inflows and Economic Growth: Evidence from China's Provinces, 19782008, Applied Economics 45(15) (2013) 2127-2139.

DOI: https://doi.org/10.1080/00036846.2012.654916

[3] R.E. Caves, Multinational Enterprise and Economic Analysis, Cambridge University Press, 2007.

[4] J.R. Markusen, A.J. Venables, Foreign Direct Investment as A Catalyst for Industrial Development, European Economic Review 43(2) (1997) 335-356. DOI: https://doi.org/10.3386/w6241

[5] B.S. Javorcik, Does Foreign Investment Increase the Productivity of Domestic Firms? In Search of Spillovers through Backward Linkages, American Economic Review 94(3) (2004) 605-627. https://doi.org/10.1257/0002828041464605

[6] K.E. Meyer, Perspectives on Multinational Enterprises on Emerging Economies, Journal of International Business Studies 35(4) (2004) 259-276.

DOI: https://doi.org/10.1057/palgrave.jibs.8400084

[7] T. Albulescu, M. Tămăşilă, The Impact of FDI on Entrepreneurship in the European Countries, Procedia - Social and Behavioral Sciences 124 (2014) 219-228. DOI: https://doi.org/10.1016/j.sbspro.2014.02.480

[8] K. De Backer, L. Sleuwaegen, Does foreign Direct Investment Crow out Domestic Entrepreneurship? Review of Industrial Organization 22(1) (2003) 67-84.

DOI: https://doi.org/10.1023/A:1022180317898

[9] M. Ayyagari, R. Kosova, Does FDI Facilitate Domestic Entry? Evidence from the Czech 
Republic, Review of International Economics 18(1) (2010) 14-29. DOI: https://doi.org/10.1111/j.1467-9396.2009.00854.x

[10] R.E. Caves, Multinational Enterprise and Economic Analysis, Cambridge: Cambridge University Press, 1996.

[11] J. Haskel, S. Pereira, M. Slaughter, Does Inward Foreign Direct Investment Boost the Productivity of Domestic Firms? Review of Economics and Statistics 89(3) (2007) 482-496. DOI: https://doi.org/10.2139/ssrn.301192

[12] R. Findlay, Relative Backwardness, Direct Foreign Investment, and the Transfer of Technology: A Simple Dynamic Model, Quarterly Journal of Economics 92(1) (1978) 1-16. DOI: https://doi.org/10.2307/1885996

[13] A. Kokko, Foreign Direct Investment, Host Country Characteristics, and Spillovers, Stockholm School of Economics, 1992.

[14] F. Barry, H. Görg, E. Strobl, Foreign Direct Investment, Agglomerations, and Demonstration Effects: An Empirical Investigation, Review of World Economies 139(4) (2003) 583-600. DOI: https://doi.org/10.2307/40440978

[15] A. Fosfuri, M. Motta, T. Ronde, Foreign Direct Investment and Spillovers through Labor Mobility, Journal of International Economics 53(1) (2001) 205-222. DOI: https://doi.org/10.1016/S00221996(00)00069-6

[16] M.E. Moretti, Peers at Work, American Economic Review 99(1) (2009) 112-145. DOI: https://doi.org/10.2307/29730179

[17] O. Bandiera, I. Barankay, I. Rasul, Social Incentives in the Workplace, Review of Economic Studies 77(2) (2010) 417-458. DOI: https://doi.org/10.1111/j.1467-937X.2009.00574.X

[18] J.J. Sandvik, R.E. Saouma, N.T. Seegert, et al., Workplace Knowledge Flows, Quarterly Journal of Economics 135(3) (2020) 1635-1680. DOI: https://doi.org/10.1093/qje/qjaa013

[19] Djankov, S., Hoekman, B., Foreign Investment and Productivity Growth in Czech Enterprises, World Bank Economic Review 14(1) (2000) 49-64. DOI: https://doi.org/10.1093/wber/14.1.49

[20] G.M. Grossman, International Trade, Foreign Investment, and the Formation of the Entrepreneurial Class, American Economic Review 74(4) (1984) 605-614. DOI: https://doi.org/10.3386/w1174
[21] National Bureau of Statistics of China, China Statistical Yearbook, China Statistics Press, 1984, 1988, 2018. 